Relations industrielles

Industrial Relations

\title{
The Structure of White-Collar Compensation and
} Organizational Performance

La structure de rémunération des cols blancs et les résultats atteints par l'organisation

\section{La estructura de compensación de los empleados de oficina y la organización eficiente}

K. C. O'Shaughnessy

Volume 53, numéro 3, été 1998

URI : https://id.erudit.org/iderudit/005296ar

DOI : https://doi.org/10.7202/005296ar

Aller au sommaire du numéro

Éditeur(s)

Département des relations industrielles de l'Université Laval

ISSN

0034-379X (imprimé)

1703-8138 (numérique)

Découvrir la revue

Citer cet article

O'Shaughnessy, K. C. (1998). The Structure of White-Collar Compensation and Organizational Performance. Relations industrielles / Industrial Relations, 53(3), 458-485. https://doi.org/10.7202/005296ar

Tous droits réservés (C Département des relations industrielles de l'Université Laval, 1998
Ce document est protégé par la loi sur le droit d'auteur. L'utilisation des services d'Érudit (y compris la reproduction) est assujettie à sa politique d'utilisation que vous pouvez consulter en ligne.

https://apropos.erudit.org/fr/usagers/politique-dutilisation/ 


\title{
The Structure of White-Collar Compensation and Organizational Performance
}

\author{
K. C. O'SHAUGHNESSY \\ Haworth College of Business, Western Michigan University, Grand Rapids, \\ Michigan.
}

Using a unique data set, this paper analyzes how the relationship between managerial compensation and firm performance changes as one moves down the organizational hierarchy. It is found that predictions of efficiency wage, agency, and tournament models of compensation differ for different hierarchical levels in organizations. The results add support to the notion that a variety of models may be necessary to explain organizational compensation strategies.

It is not surprising to see the amount of research attention focusing on pay $^{1}$ given both the amount of time and energy firms spend designing compensation schemes and the impact of pay choices on operating costs. Extensive research investigates the relationship between top executive pay and firm performance (Coughlin and Schmidt 1985; Jensen and Murphy 1990; Kerr and Bettis 1987; Lewellen et al. 1992; Murphy 1985; Tosi and Gomez-Mejia 1989, 1994). Similarly, the differences in the nature of blue-collar wages across firms and industries has been a frequent research topic (Groshen 1988; Leonard 1990). In contrast, relatively little attention has been paid to the compensation of middle managers. ${ }^{2}$ This paper extends the research themes developed on executive and production worker pay by investigating these research themes for middle managers. Specifically, it examines how the structure of their compensation is related to organizational performance.

1. See, for example, Kleiner et al. (1987), Blinder (1990), Ehrenberg (1990).

2. A recent exception is Werner and Tosi (1995) which considers middle-management compensation and ownership structure. 
The major economic theories used in most compensation research agency theory, efficiency wages, tournament models, etc. - relate compensation to the performance of firms and seem to apply more or less equally to employees at all organizational levels. But closer examination suggests that some theories may be more relevant for certain levels of the organization than for others. Differences in how these arguments apply across levels of the hierarchy may explain the mixed results found in some prior empirical tests of pay and performance.

The present research is distinctive in that it is able to compare explicitly the predictive power of different theoretical models in explaining the relationship between compensation and organizational performance. Finally, the paper examines how these various models operate at different levels of the organization. The results support the premise that different theories of compensation might be relatively more successful at explaining the relationship between compensation and organizational performance at different levels of the organizational hierarchy. I review the literature on compensation and performance and develop hypotheses grounded in this literature, then detail the research methodology used in this study, and finally discuss the results of my analysis and present conclusions based on these results.

\section{THE STRUCTURE OF COMPENSATION CHOICES}

Recent compensation research discusses the considerable discretion employers have with respect to their compensation policies. For example, Gerhart and Milkovich (1990) uncover stable differences in compensation strategies across firms. If, as Gerhart and Milkovich find, the managers of firms have some discretion concerning the attributes of their compensation program, then it is important to understand how these attributes are related to the financial performance of firms.

The three models of compensation most often considered are the agency model, efficiency wages, and tournaments. Although these three models are certainly not the only models of the relationship between pay and performance, there is considerable support for these models in prior studies. This research is best understood in comparison to the established empirical relationship and is, therefore, best focused on these models. Each model is considered in turn.

\section{Agency Model}

In the agency model (Jensen and Meckling 1976), an agent is defined as one taking action on behalf of a principal. ${ }^{3}$ When the principal cannot

3. See Levinthal (1988) and Eisenhardt (1989) for a review of agency theory. 
observe the actions of the agent, or the agent has better information on how his or her actions affect outcomes, the principal cannot easily monitor whether the agent is truly acting in the principal's best interests. If the agent's preferences or goals deviate from the principal's, then the agent has an incentive to deviate from the principal's interests. And the principal has difficulty determining how much, if any, deviation has taken place. The agency problem, then, is how the principal can minimize the losses that occur when the agent is acting on his or her behalf.

Incentive contracts that seek to make the agent's goals similar to the principal's by tying compensation to outcomes are one way to minimize the agent's deviation. For example, the manager of a firm (the agent) makes business decisions such as how much investment to make or in which markets to participate. It is often very difficult for the shareholders of the firm (the principals) to determine if these choices are maximizing the firm's profits or are instead furthering some other goal of less interest to the stockholders. If the manager values growth in addition to profitability, for example, he or she may take actions that increase the size of the firm at the expense of profits. But if the manager's compensation is based (at least in part) on the firm's profitability, he or she might pass up the opportunity to increase the size of the firm at the expense of maximizing profits. Therefore, compensation that is contingent upon firm performance will help align the goals of the manager agents with those of the stockholder principals.

Agency theory predicts that the closer incentives are to effort, the greater the agent's effort will be, in turn, the greater will be their outcomes, and, the outcomes of the organization. While a compensation plan based entirely on outcomes is inefficient for risk-averse managers, pay schemes that include some variable component will not only align interests but should also pay the agent more than pay schemes based on straight salary.

An important point concerns the specific predictions from agency theory. The theory as presented by Jensen and Meckling (1976) suggests that there is an equilibrium point where the marginal benefits (in terms of reduced shirking) of another dollar of variable pay equal the costs of inducing risk-averse managers to accept additional variable pay in place of a dollar of fixed pay. Thus, instead of suggesting that variable pay is superior to fixed pay, agency theory merely suggests that there is some equilibrium point where the costs of risk premiums to managers are balanced by the gains from reduced shirking.

Much of the research on top executive compensation relies on agency models to predict the relationship between pay and performance. 
The empirical evidence reveals some mixed support for agency models at the top of firms. Researchers have consistently found a small, but significant, relationship between the extent to which the structure of top management compensation reflects agency principles and firm performance (Coughlin and Schmidt 1985; Deckop 1988; Lewellen et al. 1992; Murphy 1985; Tosi and Gomez-Mejia 1994).

The few studies that examine data for white-collar workers below the top offices also find some weak support for the agency model. Gerhart and Milkovich (1990) find a positive, significant relationship between bonus to base ratio and firm performance across a sample of firms that includes roughly 75 top white collar managers per firm. Leonard (1990) finds bonuses related to return of equity (ROE) but not related to change in ROE. He does, however, find long-term incentives related to change in firm performance. Leonard's findings offer mixed support for the agency model.

Applying the logic connecting contingent compensation and performance to changes in compensation leads to the first hypothesis, which follows directly from previous agency research:

H1: Change in the ratio of bonus to base compensation is positively related to change in financial performance of firms.

Although the agency model predicts that contingent compensation should in general be positively associated with firm performance, a closer look suggests that this association may not be as strong at lower levels of the firm. Free rider problems reduce the effectiveness of contingent compensation as one moves further down the organization and the size of the group being evaluated grows. For example, it is much easier to identify how the efforts of the CEO relate to organizational performance than to identify similar relationships for middle managers. Because the CEO's effort has a much more direct impact on firm performance, we might expect that compensation that ties their pay to firm performance should entice them to exert more effort on behalf of the firm. For lower-level managers, in contrast, it is difficult to see how their individual contributions affect overall firm performance. Indeed, we might even expect that arrangements where their compensation is tied to firm performance would induce much less effort from them because the payoff is less certain. Borrowing from expectancy theory, because the link between performance and reward is less clear, their motivation to perform is reduced even if compensation ties their pay to firm performance. (Efforts to link the pay of lower-level managers to some intermediate performance outcomes like division or group performance is certainly one way to address the issue.) 
We expect that contingent compensation will have a lower effect at the non-supervisory white-collar levels of the firm. This suggests the following hypothesis:

H2: The relationship between bonus to base ratio and performance is weaker as one moves down the organizational hierarchy.

\section{Efficiency Wages}

Efficiency wage models suggest that firms that pay above market levels do so because the higher wages lead to superior performance from workers (Akerlof and Yellen 1986). The model suggests that this increased effort more than offsets the additional wage costs and results in increased profits. Gerhart, Milkovich, and Murray (1992) suggest that there are four interpretations of efficiency wages: (1) the higher wages encourage a better type of employee to join the firm; (2) the higher wages motivate employees to reduce shirking, even under less monitoring; (3) employees will view the premium they receive as a gift (more of a social comparison theory view) and will work harder in return; (4) higher wages reduce turnover. All four interpretations predict a positive (or perhaps just nonnegative) relationship between pay level and performance.

To date there have been few direct tests of efficiency wage theory. A notable exception is Cappelli and Chauvin's (1991a) study of the relationship between wage premiums and the likelihood an employee will take actions that risk job loss. They find support for the theory in that employees receiving a wage premium were more likely to use formal grievance systems rather than shirking or absenteeism to address conflicts. Cappelli and Chauvin (1991b) find further support for efficiency wages in a comparison of disciplinary dismissals and wages rates. They find that higher wage rates are associated with fewer disciplinary dismissals.

Similarly, Groshen and Krueger (1990) find support for efficiency wage arguments in their study of wages and supervision in hospitals. They find that wage premiums are inversely related to the amount of supervision, presumably a mechanism to reduce shirking. Campbell (1993) considers relative wages and quit rates and finds support for the efficiency wage model. Levine (1993) finds that higher paid workers in both the US and Japan are less likely to quit, more likely to be satisfied with their pay, and report that they work harder. Levine (1992) finds changes in total factor productivity related to changes in relative wages consistent with efficiency wage predictions. However, the support for efficiency wage theory is not unanimous. Both Leonard (1987) and Spitz (1993) report finding no relationship between high relative wages and productivity. 
Changes in the wage premium ought to be related to changes in individual performance. As firms increase the premium they pay their employees, the employees have more to lose and therefore will exert more effort in order to keep their jobs. On the other hand, because wage premiums raise organizational costs, whether firm performance as a whole improves depends on whether the increase in individual effort offsets the higher wage costs. We therefore test the more general hypothesis that changes in the wage premium are related to changes in firm performance.

H3: Changes in the relative wages managers are paid are positively related to changes in the performance of firms.

The studies mentioned above find some support for efficiency wage models at the blue-collar level, but the few studies that examine managerial jobs find no support for these models. Gerhart and Milkovich (1990) find that firms that pay their managers relatively higher wages do not exhibit relatively higher financial performance. Leonard's (1990) results are similar.

As a practical matter, managers near the top of the organizational hierarchy are much less attached to outside labour markets. The jobs they hold tend to become more idiosyncratic and often rely more on firm-specific skills. As compared to lower-level jobs, the more important rewards are more likely to be the possibility of promotion (see below) and contingent compensation. As a result, individuals in these jobs find it more difficult to benchmark their jobs to the outside labour market. Because of these other factors - promotion prospects, contingent pay, idiosyncratic skills and conditions, etc. - it is much more difficult for them to judge whether their job is paid a wage premium, particularly based on base salary. Efficiency arguments should therefore be less applicable as one moves up the organizational hierarchy:

H4: The relationship between efficiency wages and firm performance is weaker for top managers than for lower level white-collar employees.

\section{Tournament Theory}

A third attribute of compensation plans that theoretically affect firm performance is the steepness of the relationship between compensation and the promotion hierarchy. Tournament theory (Rosen 1986) suggests that managers are motivated in part by the value of the future wages associated with promotions. In this model, employees are engaged in a succession of tournaments with the prize being a promotion to the next level where the pay is disproportionately greater. The essence of tournament arguments is that the pay at higher levels in the promotion ladder should 
more than compensate for the additional duties of those jobs and should constitute something of a "prize" that makes the job attractive and motivates subordinates to try to achieve it.

Tournament models of compensation solve some of the information problems inherent in trying to align compensation with performance. An employee's performance is the product of their own effort and skills as well as a series of factors that are beyond their control which might be thought of as luck, or more formally, "noise" - developments in their area such as new equipment or techniques, changes in the rest of the firm, or in product markets, etc. If managerial compensation is based on their outcomes, then some of their compensation is also based on noise that is outside their control. A manager could conceivably exert extraordinary effort and still receive no compensation if industry or market factors adversely affect the firm's financial performance. Not only does this loosen the relationship between effort and reward, reducing expectancybased motivation, but risk-averse managers should require higher expected compensation in order to accept a compensation plan where pay is shaped by random outcomes.

Under tournament theory models, however, managers are evaluated relative to the performance of their peers. Since all of the managers in a tournament are subject to similar random forces, the comparison of one manager's output to another's output should, in theory, better reflect differences in individual effort and ability. ${ }^{4}$

Managerial effort is influenced by the size of the salary gradient between levels (the prize for winning a tournament) and the probability of being promoted (Rosen 1986; Lazear 1992). While Leonard (1990) finds evidence supporting the suggestion that pay hierarchies resemble tournament structures, he suggests that the relationship between steepness and performance is positive but finds no empirical support for this suggestion.

Ehrenberg and Bognanno (1990) study tournaments using the PGA tour as an analogy for corporate promotional tournaments. They find significant evidence supporting the relationship between effort and prize spreads. Similarly, Becker and Huselid (1992) investigate tournament relationships in auto racing and find that as the tournament prize grows, racing speeds increase. The evidence suggests that, in professional sports, the design of tournament prizes influences the motivation of participants.

4. The random part of outcomes is really a combination of randomness in the economy, at the firm level, and at the individual level. Tournaments that use relative performance eliminate the effect of the aggregate portions of the total risk. Managers are, then, rewarded for their effort without incurring large risks. 
Parallel results in the corporate arena, on the other hand, are less common. Lambert, Larcker, and Weigelt (1993) compare the relative merits of tournament, agency, and managerial power models in explaining observed compensation patterns using an extensive data set similar, in many ways, to the data used in this study. They find support for a combination of the models as descriptors of compensation structures. Their support of tournament explanations is perhaps their most interesting finding. First, tournament models offer an explanation for the large observed premium paid to CEOs. Given the recent heavy criticism focused on the "exorbitant" salaries paid to CEOs, evidence of a model that supports large premiums paid to CEOs is especially important. Second, tournament type compensation schemes offer an efficient form of ex-post settling that is highly reliant on managers' expectations. With the recent corporate cutbacks, managerial careers are far more uncertain. This influences the expected payouts of the tournaments (or as Lambert et al. point out "the option value").

Cappelli and Cascio (1991), Bull, Schotter, and Weigelt (1987), and Weigelt, Dukerich, and Schotter (1989) all find some evidence that compensation systems inside firms in some way resemble tournaments. On the other hand, the evidence is not unanimous, O'Reilly, Main, and Chrystal (1988) do not find support for tournament models in their test of top management compensation.

H5: Changes in the steepness in the salary grade are positively related to changes in a firm's performance.

The extent to which a premium for promotion is a motivating factor for employees may depend on how they weigh the option of advancing within the firm versus moving for better opportunities at other firms. Employees at the lower levels, especially in non-management professional positions, may be the least interested in promotion opportunities as they have less clearly defined promotion paths and greater mobility on the outside with jobs that are reasonably similar.

H6: The tournament model should be more predictive of the relationship between pay and performance at upper levels of the firm than at lower levels.

METHOD

Sample

The compensation data used in this study come from Hay Associates' Annual Compensation Survey database. Each year Hay sends to its "mem- 
bers" a survey designed to address current topics in compensation and a form to fill out regarding the salary, bonus, job points, job level, job function, zip code, and division of white-collar clerks to CEO's. This paper is based on an analysis of Hay's data base from the years 1986, 1989, 1992. In each of the three years, over 45,000 white collar positions are included in the database. This rich data base allows an examination of the structure of wages deep into the organizations and of how they change over time.

The 45,000 white-collar employees work for 35 publicly traded industrial firms. The firms are similar to the Fortune 500 in profitability $(4.7 \%$ ROA for the sample vs. $4.6 \%$ for the Fortune 500 ), size (\$6.4 B in assets for the sample vs. $\$ 4.6 \mathrm{~B}$ for the Fortune 500 ), and sales ( $\$ 5.0 \mathrm{~B}$ in sales in 1989 vs. $\$ 4.3$ for the Fortune 500). The firms are distributed over 15 industries (2-digit SIC). They separate into 8 industry groups including: Mining/ extraction (3 firms), Food (5 firms), Paper/publishing (3), Chemicals (4), Equipment/Machinery (7), Railroad (5), Utilities (4), Communications (4). The firms represent a fairly random collection of industrial firms (SIC 20-40).

The firms examined here are certainly not representative of all firms. In addition to the bias toward larger, industrial firms, perhaps the most important bias is toward the inclusion of stable, older firms. For a firm to be included in the data base it needed to be a participant in Hay's salary survey in all three years $(1986,1989,1992)$.

As a result, the data are both right and left censored: there is no information on "births" (or new firms) or on "deaths" (or firms that have folded). Further, firms that are in financial difficulty might well withdraw from the Hay project. If a firm is threatened with extinction, it probably loses interest in how its employee's salaries compare with the salaries of employees at other firms.

The net effect of this sample is to limit the generalizability of the results. Nevertheless, the sample is representative of large, stable, industrial firms, a category that may be declining in importance in the US but remains of considerable interest. Given the similarity between these firms and the mean performance of the Fortune 500, this sample appears representative of those firms.

Firms pay to participate in the survey, thereby increasing their incentive to report accurately. They also use the information contained in the database to set compensation levels, arguably increasing their interest in a reliable database. 


\section{Measures}

\section{Modelling Change}

Traditional research which relates the level of firm performance to some characteristic of compensation structure is open to the criticism that omitted variables associated with the structure of compensation are driving performance outcomes. For example, firms in particular industries may attract particularly able executives who demand that their compensation be structured in a certain way. Apparent relationships between the structure of compensation and firm performance may, in fact, be the result of superior executives driving both.

Examining the relationship between changes in the structure of compensation and firm performance requires a shift from cross-sectional to longitudinal research. The advantage of longitudinal research is that because we are comparing the same firms over time, most of the characteristics of those firms that might cause spurious relationships with performance are common across the periods and are therefore controlled for in the analysis. Thus, in the models used here, changes in compensation attributes are compared with changes in firm performance.

Using change scores like these has been hotly debated (Edwards 1994). They have been used and defended in the compensation literature because compensation data do not suffer as much from as high systematic errors and unreliability as the psychological measures normally discussed in that literature (Werner and Tosi 1995). Still, the use of change scores in the regression models does require some caution (Finkel 1995; Allison 1990). ${ }^{5}$ When the component measure at time t-1 has an influence on the component measure at time t, the change score may be unreliable. The solution Finkel presents to this problem is to include both pieces of the dependent variable in the equation. Thus, in addition to performing our analysis using the change scores described below, the data is also analyzed using the static score model suggested by Finkel. This represents a more conservative test of the hypotheses and should overcome any reliability concerns associated with the use of change scores.

5. The use of difference scores has been more controversial than the use of change scores. As Tisak and Smith (1994: 675) suggest "We define difference scores as the difference between distinct but conceptually linked constructs. This definition should not be confused with change scores, or the difference between a single construct measured at two or more points in time." The battle over the adequacy of differences scores (Edwards 1994) focuses on the difference between two distinct variables measured concurrently. While debates are concerned with the reliability of the resultant measure, the sources of reliability problems are different. 


\section{Performance}

The dependent variable used in our analysis is change in ROA. Using ROA allows a comparison with prior research (Gerhart and Milkovich 1990; Lambert, Larcker, and Weigelt 1993; Werner and Tosi 1995). Returns (net income) and assets (total assets) were obtained from the COMPUSTAT tapes. For each firm there are three observations (1986, 1989, 1992) allowing for the calculation of two change periods. This provides a pooled sample of 70 observations for analysis. Thus, change in ROA is the difference between ROA(t) and ROA(t-3).

\section{Levels}

The firms participating in the survey identify each employee's position in the organizational hierarchy according to the following scheme:

Level $1=$ Executive managers with direct profit and loss responsibility (e.g., group vice president)

Level $2=$ General management, managers who manage other managers (e.g., division controller)

Level 3 = Supervisors or managers of non-supervisory employees (e.g., manager of accounts payable)

Level 4 = Exempt, non-supervisory employees (e.g., accountant)

For each of the compensation variables we calculate the mean of the variable for each level in each firm and compute the change in each.

These definitions of the levels of the organizations provides us with a structure to make comparisons across firms. There are some complications, however. The most important issue is that this structure does not necessarily map onto a given firm's organizational chart which might have more that four levels between the CEO and non-supervisory employees. In practice, most of the other levels inside a firm will be compressed into level 2 in this coding scheme. For example, in a firm with 10 levels between the CEO and non-supervisory employees, seven of those would likely be compressed into level 2. As noted below, however, because the paper compares changes in compensation profiles over time across firms and by level, differences across firms in the make-up of their levels should wash out.

\section{Compensation Variables}

The main independent variables are the measures of three classes of compensation: relative pay level (designed to examine efficiency wage issues), pay mix (to explore agency arguments), and steepness (to proxy tournament models). The measurement of pay levels, BASE/MARKET, is 
calculated similarly to the techniques used in Gerhart and Milkovich (1990), Leonard (1990) and Levine (1993). The relative pay level is a measure of how the wages of the managers in a firm relate to similar managers in other firms. The idea is to calculate the extent to which wages in a given firm and level are paid a premium over the market average for those positions calculated after controlling for firm- and level-specific factors such as job requirements that might demand greater compensation.

We begin by calculating a regression of pay on skills (Hay's measure of skills is discussed below) and job function for all of the managers across firms within each level. From this equation I calculate the residual for each manager and then compute the mean residual for each level of each firm. The residual for each employee represents the amount above or below the market wage. Therefore, if a firm on average pays its level 2 managers more than level 2 managers in other firms with comparable skills, the mean residual will be positive.

The BASE/MARKET measure used in the regression is measured as the difference between the mean residual for each level between two time periods (i.e., BASE/MARKET = mean residual 1992 - mean residual 1989). Thus, for each firm there are two change periods resulting in two values of BASE/MARKET. The two change periods are pooled and the regression models are run on the resulting 70 observations.

The Hay data includes measures of individual skill levels (Hay Points). The Hay points associated with a specific job are designed to capture the generic skills that the job requires. Hay measures the know-how, problem solving, and accountability of each job in the member organizations and assigns Hay points to the job based on the set of skills required (see Cappelli 1993).

There are advantages in using Hay's measure of skills to help calculate the market wage for a job. The Hay system is very thorough and consistent over time, thereby allowing meaningful comparisons across firms and across time. First, in contrast to most studies, it measures the skills required by the job rather than the attributes of the individual incumbents in those jobs; job requirements are the factor that is most important in determining wages as firms are unlikely to pay for attributes that are irrelevant to job requirements.

Hay points are not perfect measures, however. There is no way of testing whether changes in skill demands are incorporated into the three categories of know-how, problem-solving, and accountability. If changes in job requirements that affect market wages are not picked up by skill points, then the BASE/MARKET measure creates an artificially high residual in the pay level (efficiency wages) equation. Therefore, if some firms 
systematically require skills that the Hay system does not measure and pays managers for these skills, the measures of relative wages will be exaggerated for these firms.

But, in general, Hay points seem much better controls for market skills than those typically used. Most other studies use much simpler measures as controls in calculating wage premiums (including education, number of subordinates, etc.) and miss aspects of job requirements that the Hay system measures. The result is that the measure of BASE/MARKET used here is less noisy than the regressions that use the simpler controls.

The second measure of compensation strategy is pay mix (BONUS/ BASE). This is the mean ratio of total cash compensation to base salary for each level of each firm. This measure is also used in Leonard (1990) and Gerhart and Milkovich (1990). One strength of this measure is that it is available in this data set for all of the employee positions being examined. For middle managers and below, cash bonuses generally represent the extent of contingent compensation which these managers receive. For top executives, stock holdings, stock options, and wealth effects may overwhelm annual cash bonuses so the relationship between pay mix and performance for this group may suffer from omitted variable biases if pay mix is the only variable included.

BONUS/BASE is calculated for each level of each firm as:

(mean total cash compensation/mean base salary) $)_{t}$ (mean total cash compensation/mean base salary) $\mathrm{t}_{\mathrm{t}-3}$

(mean total cash compensation/mean base salary) t-3

The third aspect of compensation strategy measured is the steepness of the compensation strategy (STEEPNESS). Many studies follow Leonard (1990) in measuring steepness as the ratio of mean pay between upper and lower levels of the organizational hierarchy. In this study, this measure is constructed for each organizational level in comparison with the level directly above it. In other words, the STEEPNESS measure for non-supervisory, exempt employees is calculated as the ratio of mean wages level 3 to mean wages level 4 multiplied by the ratio of the number of employees at level 3 to the number of employees at level 4 . This captures the incentive effect of the "prize" as it considers the value of the promotion and the likelihood of winning a promotion. The STEEPNESS variable is computed as a change score similar to BONUS/BASE.

\section{Controls}

To control for industry effects, we include both of the dummy variables covering the industry groups discussed above and change in industry ROA. The natural log of sales is included as a control for size. 


\section{ANALYSIS}

The analysis begins with the following OLS regression model estimating the relationship between pay attributes and firm performance:

Change in $\mathrm{ROA}=\mathrm{a}+\mathrm{b} 1($ Change in Pay Mix $)+\mathrm{b} 2$ (Change in Relative Pay Level) + b3(Change in Pay Steepness) $+\mathrm{e}$

This model is estimated for each of the four management levels. Controls for the effect of firm size and industry are then included, in part because previous studies like Gerhart and Milkovich (1990) and Leonard (1990) find stable industry effects on wage levels. Jensen and Murphy (1990) find changes in the pay and performance relationship between large and small firms. The natural log of sales is included as a consideration of size in our model. To control for changes in profitability at the industry level, we include the change in industry ROA

Finally, we consider a model that tests for differences between levels. The regression coefficients for each of the three pay attributes is estimated separately including the values for each level in one model. In order to make some comparison of effects between levels, we calculate the regressions using standardized values of the variables. This model allows a testing of the hypotheses concerning the relative impact of each pay attribute across levels.

\section{RESULTS}

Table 1 presents the correlation matrix of the variables used in the regressions. The great majority of the correlations show few troubling intercorrelations.

However, table 2 shows the correlations of attributes across levels. In this table, the correlations between the levels for BONUS/BASE and BASE/ MARKET are quite large. It is this colinearity that prompts the regressions in table 4 (discussed below).

Table 3 presents the regression of change in performance on changes in pay attributes for each organizational level. The regression results provide strong support for hypothesis 1, suggesting that changes in bonus/ base are related to changes in performance at all levels of the hierarchy. The coefficient for change in bonus/base is statistically significant for each level. As table 2 indicated above, however, the Bonus/Base measures are correlated across levels, suggesting that the results at any one level are not simply capturing the unique effects at that level but also include the effects of Bonus/Base variables at other levels as well. 
TABLE 1

Means, Standard Deviations and Correlations

\begin{tabular}{|c|c|c|c|c|c|c|c|c|c|c|c|c|c|c|c|c|}
\hline & Mean & S. D. & 1 & 2 & 3 & 4 & 5 & 6 & 7 & 8 & 9 & 10 & 11 & 12 & 13 & 14 \\
\hline 1. Bonus/base level=1 & 0.01 & & & & & & & & & & & & & & & \\
\hline 2. Base/market level=1 & 3179 & 29659 & 0.15 & & & & & & & & & & & & & \\
\hline 3. Steepness level=1 & 0.06 & 0.38 & -0.06 & -0.19 & & & & & & & & & & & & \\
\hline 4. Bonus/base level=2 & 0.015 & 0.07 & 0.77 & 0.23 & -0.01 & & & & & & & & & & & \\
\hline 5. Base $/$ market level $=2$ & -663 & 13451 & 0.38 ** & 0.78 & -0.22 & $0.33^{*}$ & & & & & & & & & & \\
\hline 6. Steepness level=2 & 0.03 & 0.23 & 0.41 ** & ${ }^{*} 0.34^{* *}$ & 0.01 & $0.25^{*}$ & $0.34^{*}$ & & & & & & & & & \\
\hline 7. Bonus/base level=3 & 0.009 & 0.03 & 0.47 ** & -0.19 & -0.13 & $0.49 * *$ & * $-0.26^{*}$ & 0.06 & & & & & & & & \\
\hline 8. Base $/$ market level=3 & 334 & 2271 & 0.08 & $0.25^{*}$ & 0.05 & 0.16 & $0.37^{* *}$ & ${ }^{*} 0.11$ & -0.28 & & & & & & & \\
\hline 9. Steepness level=3 & 0.02 & 0.15 & 0.08 & 0.12 & -0.08 & 0.05 & 0.13 & -0.04 & -0.13 & 0.19 & & & & & & \\
\hline 10. Bonus/base level $=4$ & 0.006 & 0.03 & $0.45^{* *}$ & ${ }^{*} 0.10$ & 0.11 & $0.45^{* *}$ & * -0.16 & 0.08 & 0.74 ** & -0.21 & 0.06 & & & & & \\
\hline 11. Base $/$ market level $=4$ & 47 & 2175 & 0.08 & 0.23 & -0.01 & 0.13 & $0.36^{* *}$ & ${ }^{*} 0.16$ & $-0.28 *$ & $0.69 * *$ & * 0.16 & $-0.27^{*}$ & & & & \\
\hline 12. Steepness level=4 & 0.01 & 0.03 & -0.09 & 0.10 & 0.06 & 0.07 & -0.04 & 0.16 & 0.03 & -0.08 & $-0.50 * *$ & -0.08 & $-0.31^{*}$ & & & \\
\hline 13. Change in ROA & -0.005 & 0.09 & 0.60 ** & 0.02 & 0.09 & $0.44^{* *}$ & * 0.15 & $0.23^{*}$ & 0.30 * & 0.15 & 0.01 & 0.24 * & 0.09 & 0.12 & & \\
\hline $\begin{array}{l}\text { 14. Change in Industry } \\
\text { ROA }\end{array}$ & 0.004 & 0.06 & $0.45^{* *}$ & 0.09 & 0.07 & $0.39 * *$ & * 0.16 & $0.21^{*}$ & $0.25^{*}$ & 0.04 & 0.03 & $0.24^{*}$ & 0.05 & 0.18 & $0.52^{* *}$ & \\
\hline 15. LnSales & 7.35 & 1.26 & 0.01 & 0.01 & 0.18 & 0.18 & -0.01 & 0.06 & 0.08 & -0.05 & -0.10 & 0.02 & 0.02 & 0.04 & -0.01 & 0.09 \\
\hline
\end{tabular}

$$
\begin{aligned}
& \mathrm{n}=70 \\
& { }^{*} \mathrm{p}<.05
\end{aligned}
$$$$
* * \mathrm{p}<.01
$$ 
TABLE 2

Correlations Between Levels

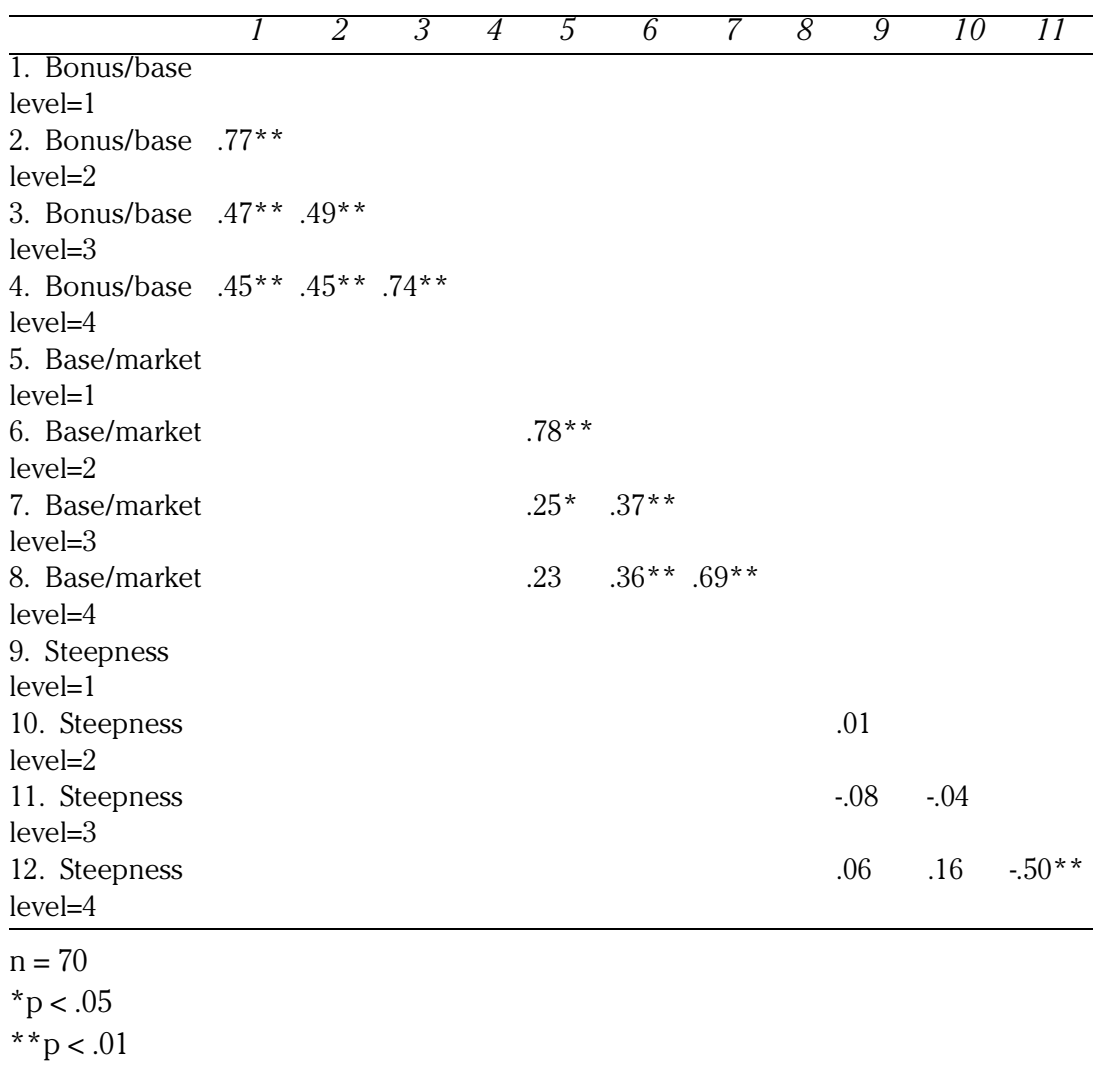

The regressions examining these relationships across levels are presented in table 4 . If some of the results in table 2 suffer from the possibility that the significant effects at one level are in part driven by correlations with pay attributes at other levels, then the results in this table may suffer from the reverse problem: where attributes are colinear across levels in the same regression, it may make some results insignificant because of multicolinearity.

The regression model considering changes in BONUS/BASE reveals strong support for hypothesis 2 . When changes in BONUS/BASE for each level are included in one model, the change for level 1 is the only one that is significant. Comparing this result with those in table 3 suggests that changes in contingent compensation for top managers drive changes in 
TABLE 3

Regression of Change in ROA on Pay Attributes by Hierarchical Level

\begin{tabular}{|c|c|c|c|c|c|c|c|c|c|c|c|c|}
\hline & \multicolumn{3}{|c|}{ Mgmt Level $=1$} & \multicolumn{3}{|c|}{ Mgmt Level $=2$} & \multicolumn{3}{|c|}{ Mgmt Level $=3$} & \multicolumn{3}{|c|}{ Mgmt Level $=4$} \\
\hline & Model 1 & Model 2 & Model 3 & Model 1 & Model 2 & Model 3 & Model 1 & Model 2 & Model 3 & Model 1 & Model 2 & Model 3 \\
\hline Intercept & $\begin{array}{l}0.01 \\
(0.157)\end{array}$ & $\begin{array}{l}-0.005 \\
(-0.086)\end{array}$ & $\begin{array}{l}0.04 \\
(0.793)\end{array}$ & $\begin{array}{l}-0.25^{*} \\
(-1.82)\end{array}$ & $\begin{array}{l}-0.28^{* *} \\
(-2.73)\end{array}$ & $\begin{array}{l}-0.10 \\
(-1.07)\end{array}$ & $\begin{array}{l}-0.007 \\
(-0.054)\end{array}$ & $\begin{array}{l}-0.02 \\
(-0.185)\end{array}$ & $\begin{array}{l}0.138 \\
(1.62)\end{array}$ & $\begin{array}{l}-0.19 \\
(-1.16)\end{array}$ & $\begin{array}{l}-0.23 \\
(-1.605)\end{array}$ & $\begin{array}{l}-0.041 \\
(-0.348)\end{array}$ \\
\hline Chg in Bonus/Base & $\begin{array}{l}0.347^{* * *} \\
(6.083)\end{array}$ & $\begin{array}{l}0.349^{* * *} \\
(6.302)\end{array}$ & $\begin{array}{l}0.225^{* * *} \\
(4.28)\end{array}$ & $\begin{array}{l}0.51^{* * *} \\
(2.978)\end{array}$ & $\begin{array}{l}0.48^{* * *} \\
(3.027)\end{array}$ & $\begin{array}{l}0.26^{*} \\
(1.856)\end{array}$ & $\begin{array}{l}1.35^{* * *} \\
(3.073)\end{array}$ & $\begin{array}{l}1.36^{* * *} \\
(3.367)\end{array}$ & $\begin{array}{l}0.73^{* *} \\
(2.23)\end{array}$ & $\begin{array}{l}1.16^{* *} \\
(2.57)\end{array}$ & $\begin{array}{l}1.08^{* *} \\
(2.51)\end{array}$ & $\begin{array}{l}0.44 \\
(1.23)\end{array}$ \\
\hline Chg in Base/Market & $\begin{array}{l}-1.9 * 10-7 \\
(-0.512)\end{array}$ & $\begin{array}{l}-2.3^{*} 10-7 \\
(-0.613)\end{array}$ & $\begin{array}{l}-2.4^{*} 10-7 \\
(-0.80)\end{array}$ & $\begin{array}{l}-8.3 * 10-7 \\
(-0.874)\end{array}$ & $\begin{array}{l}-8.7 * 10-7 \\
(-0.968)\end{array}$ & $\begin{array}{l}-6.6 * 10-7 \\
(-0.867)\end{array}$ & $\begin{array}{l}1.1^{*} 10-5^{*} \\
(1.767)\end{array}$ & $\begin{array}{l}1.2^{*} 10-5^{*} \\
(2.169)\end{array}$ & $\begin{array}{l}\text { *.7* } 10-6 * * \\
(2.23)\end{array}$ & $\begin{array}{l}1.1^{*} 10-5^{*} \\
(1.57)\end{array}$ & $\begin{array}{l}1 .{ }^{*} 10-5^{*} \\
(1.75)\end{array}$ & $\begin{array}{l}5.5^{*} 10-6 \\
(1.09)\end{array}$ \\
\hline Chg in Steepness & $\begin{array}{l}0.025 \\
(1.071)\end{array}$ & $\begin{array}{l}0.01 \\
(0.614)\end{array}$ & $\begin{array}{l}0.02 \\
(1.094)\end{array}$ & $\begin{array}{l}0.25^{* * *} \\
(3.25)\end{array}$ & $\begin{array}{l}0.26^{* * *} \\
(3.42)\end{array}$ & $\begin{array}{l}0.14^{* *} \\
(2.08)\end{array}$ & $\begin{array}{l}0.025 \\
(0.302)\end{array}$ & $\begin{array}{l}0.01 \\
(0.125)\end{array}$ & $\begin{array}{l}-0.081 \\
(-1.285)\end{array}$ & $\begin{array}{l}0.22 \\
(1.62)\end{array}$ & $\begin{array}{l}0.21^{*} \\
(1.67)\end{array}$ & $\begin{array}{l}0.09 \\
(0.936)\end{array}$ \\
\hline Log Sales & $\begin{array}{l}-0.005 \\
(-0.50)\end{array}$ & $\begin{array}{l}-0.004 \\
(-0.43)\end{array}$ & $\begin{array}{l}-0.01 \\
(-0.78)\end{array}$ & $\begin{array}{l}-0.002 \\
(-0.21)\end{array}$ & $\begin{array}{l}-0.002 \\
(-0.202)\end{array}$ & $\begin{array}{l}-0.009 \\
(-1.17)\end{array}$ & $\begin{array}{l}-0.003 \\
(-0.217)\end{array}$ & $\begin{array}{l}-0.003 \\
(-0.35)\end{array}$ & $\begin{array}{l}-0.01 \\
(-1.45)\end{array}$ & $\begin{array}{l}-0.002 \\
(-0.142)\end{array}$ & $\begin{array}{l}-0.003 \\
(-0.03)\end{array}$ & $\begin{array}{l}-0.009 \\
(-1.21)\end{array}$ \\
\hline $\begin{array}{l}\text { Chg in Industry } \\
\text { ROA }\end{array}$ & & & $\begin{array}{l}1.09^{* * *} \\
(5.09)\end{array}$ & & & $\begin{array}{l}1.16^{* * *} \\
(4.99)\end{array}$ & & & $\begin{array}{l}1.39^{* * *} \\
(6.47)\end{array}$ & & & $\begin{array}{l}1.38 * * * \\
(6.14)\end{array}$ \\
\hline Industry Dummies & YES & NO & NO & YES & NO & NO & YES & NO & NO & YES & NO & $\mathrm{NO}$ \\
\hline F & 3.67 & 10.05 & 21.03 & 2.22 & 6.61 & 12.38 & 1.22 & 3.28 & 12.78 & 1.02 & 2.10 & 10.26 \\
\hline R2 & .45 & .40 & .58 & .34 & .31 & .51 & .22 & .18 & .52 & .19 & .12 & .46 \\
\hline Adj. R2 & .33 & .36 & .54 & .19 & .26 & .47 & .04 & .12 & .48 & .01 & .06 & .42 \\
\hline
\end{tabular}

$\mathrm{n}=70$

${ }^{*} \mathrm{p}<.10$

** $p<.05$

${ }^{* * *} \mathrm{p}<.01$ 
TABLE 4

Regression of Change in ROA on Pay Attributes

\begin{tabular}{|c|c|c|c|}
\hline & Model 1 & Model 2 & Model 3 \\
\hline Intercept & $\begin{array}{l}0.05 \\
(0.52)\end{array}$ & $\begin{array}{l}0.08 \\
(0.797)\end{array}$ & $\begin{array}{l}-0.11 \\
(-0.746)\end{array}$ \\
\hline Chg in Bonus/Base Level= 1 & $\begin{array}{l}0.60 * * * \\
(4.01)\end{array}$ & & \\
\hline Chg in Bonus/Base Level=2 & $\begin{array}{l}-0.21 \\
(-1.47)\end{array}$ & & \\
\hline Chg in Bonus/Base Level=3 & $\begin{array}{l}0.16 \\
(1.17)\end{array}$ & & \\
\hline Chg in Bonus/Base Level=4 & $\begin{array}{l}-0.18 \\
(-1.41)\end{array}$ & & \\
\hline Chg in Base/Market Level=1 & & $\begin{array}{l}-0.13 \\
(-0.809)\end{array}$ & \\
\hline Chg in Base/Market Level=2 & & $\begin{array}{l}0.09 \\
(0.553)\end{array}$ & \\
\hline Chg in Base/Market Level=3 & & $\begin{array}{l}0.16 \\
(1.14)\end{array}$ & \\
\hline Chg in Base/Market Level=4 & & $\begin{array}{l}-0.05 \\
(-0.37)\end{array}$ & \\
\hline Chg in Steepness Level=1 & & & $\begin{array}{l}0.019 \\
(0.977)\end{array}$ \\
\hline Chg in Steepness Level=2 & & & $\begin{array}{l}0.14^{* *} \\
(2.305)\end{array}$ \\
\hline Chg in Steepness Level=3 & & & $\begin{array}{l}-0.06 \\
(-0.98)\end{array}$ \\
\hline Chg in Steepness Level=4 & & & $\begin{array}{l}0.001 \\
(0.011)\end{array}$ \\
\hline Industry ROA & $\begin{array}{l}0.61 * * * \\
(4.90)\end{array}$ & $\begin{array}{l}0.86 * * * \\
(6.72)\end{array}$ & $\begin{array}{l}0.69 * * * \\
(5.88)\end{array}$ \\
\hline $\mathrm{F}$ & 17.12 & 10.02 & 11.61 \\
\hline $\mathrm{R} 2$ & .57 & .44 & .48 \\
\hline Adj. R2 & .54 & .39 & .44 \\
\hline
\end{tabular}

${ }^{a}$ Data presented are standardized coefficients, with t-statistics in parentheses.

$\mathrm{n}=70$

${ }^{*} \mathrm{p}<.10$

$* * \mathrm{p}<.05$

$* * * \mathrm{p}<.01$ 
performance and the apparent relationship between changes in contingent compensation for lower level managers and firm performance is due to the fact that changes in contingent compensation are correlated across organizational levels. The standardized regression coefficients suggest that a .6 of a standard deviation change in bonus/base is related to a 1 standard deviation change in performance. This is substantially larger than the changes in the other levels which are not statistically differentiable from zero.

The regressions in table 3 provide some support for hypothesis 3 which tests the relationship between efficiency wages and performance. At the lower white-collar levels, the relationship between BASE/MARKET and performance is statistically significant. This is particularly true at level 3 (managers who supervise non-supervisors). The significant results for level 4 hold with industry controls but not when change in industry ROA is included. As table 2 indicates, BASE/MARKET is highly correlated between levels 3 and 4 , so the level 3 and 4 results may be intertwined.

None of the standardized coefficients for the BASE/MARKET variable are statistically significant when all levels are included in the same equation. The significant results for level 3, and to some extent level 4, disappear when placed in the same regression, no doubt because of the multicolinearity (table 2 shows BASE/MARKET correlated at .69 across levels 3 and 4). Taken together, these results seem to suggest that there may well be significant effects on organizational performance of efficiency wages as measured by the BASE/MARKET variable at the supervisor and exempt levels of the organization. These results offer some weak support for hypothesis 4 .

The results for the steepness variable are perhaps easier to interpret as the correlations in table 2 suggest that steepness of the compensation hierarchy is not closely correlated across levels. These results support the tournament model (hypothesis 5) only for level 2, i.e., for managers of supervisors.

The results for the STEEPNESS variable in table 4 reinforce the earlier results showing support for the tournament model at level 2 (hypothesis 6). The relationship between the steepness of the hierarchy and changes in performance is much stronger at level 2 than it is at the other levels. It is, however, less strongly related to the independent variable than BONUS/ BASE. This is shown by the difference in the standardized coefficients ( 0.6 vs 0.14 ).

As a check of the reliability of our change score model, we also regressed performance at time t on changes in compensation choices controlling for performance at time $\mathrm{t}-1$ and compensation at $\mathrm{t}-1$. The 
results of this static score model (Finkel 1995) offer the same support for our hypotheses as the unconditional change models in tables 3 and 4 . Given that the results are invariant relative to the characterization of the change measures, it was decided to present the model that employs the traditional change score because it is consistent with prior research (e.g., Leonard 1990; Gibbons and Murphy 1990; Werner and Tosi 1995; Kerr and Kren 1992; Lambert et al. 1991).

\section{CONCLUSION}

The answer to the primary question investigated in this study, "Does the relationship between pay and performance vary through the levels of the hierarchy?", is affirmative. The evidence shows that the relationship between pay and performance is different for lower level managers and staff than it is for upper management.

This primary result is important for a number of reasons. First, while tying top managers's compensation to the financial performance of firms is a rather straightforward way to reduce agency problems, it may not be the optimal way to improve the efforts and focus of middle managers. In fact, motivating middle managers through efficiency wages may be more appropriate. Managers, then, need to consider how the potential impact of compensation choices matches the desired impact when designing compensation strategies.

The results supporting hypotheses 1 and 2 suggest that the agency model has predictive ability in the upper levels of organizations but is less predictive for lower levels of white-collar workers. The lack of a strong association between contingent pay and firm performance at the lower levels might be the result of free rider problems. The employees at this level may have difficulty seeing the connection between their increased efforts and increases in the size of their bonuses.

Comparing our results with the results from research investigating executive compensation suggests that the lessons learned from the study of executive compensation may not extend to lower levels of organizations. This is important in light of the extent to which executive compensation has been researched. This point is particularly salient for agency models. The modest gains in performance attributed to aligning the compensation of executives with the performance of firms are not very costly to the organization because paying large contingent bonuses to a few executives has a small impact on total compensation and benefits costs. However, the cost of contingent compensation becomes considerably more important when large parts of the organization are involved. If the 
bonuses paid to a large portion of the workforce do not motivate significant changes in performance, then the substantial rise in total compensation costs is not warranted.

The efficiency wage model receives more support for lower levels of white-collar workers than it does for upper levels. Higher level workers may be more unique to their jobs than lower level workers and therefore lack the market comparisons essential to the use of efficiency wages. Lower level workers may be less motivated by contingent wages due to free rider problems and thereby more strongly influenced by efficiency wages given the more direct reward/punishment relationship established by efficiency wages. Concurrent with the decreased job security among white-collar workers it would be interesting to investigate whether efficiency wages paid to white-collar workers produce greater effort.

The results of this study also suggest that a variety of models of compensation may explain how firms compensate their employees. This result is consistent with the prior research that examined a variety of compensation attributes simultaneously. Effective compensation strategies must consider the full range of attributes in order to more effectively motivate employees.

The success of each of the three models of compensation at different levels of organizations may, in part, explain the inconsistent results found in prior studies. For example, the lack of support for efficiency wage models for upper level managers may not be a rejection of the model but instead a rejection of the model for classes of employees with unique skills. Likewise, tournament models may be most predictive for those employees who view themselves as attached to internal labour markets and the promotion tournament. Future research may seek to understand employee perceptions of compensation plan attributes and how these perceptions motivate behaviour.

This research has important implications for compensation managers. First, the results suggesting that changes in compensation program attributes are associated with changes in firm performance imply that the design of compensation programs can lead to important outcomes at the organizational level. Second, the support found for all three of the economic theories of compensation suggests that compensation managers need to incorporate a variety of attributes into their plan designs. Finally, the most important implication for compensation managers is that there is no "silver bullet" for compensation plans. Each company must design plans that have attributes that are salient to each class of employee. Stock option plans may be appropriate for upper management and ineffective for lower level managers. Similarly, lower level managers may be best 
motivated by compensation plans that pay an efficiency wage. Effective compensation managers will design compensation plans that incorporate a variety of attributes that best fit their workforce and their circumstances.

There are some limitations to this research that need to be noted. First, trying to determine which independent variable has more influence among a set of correlated variables often leads to inconclusive results, as shown with the cross levels base/market models. Second, the equations we estimate cannot rule out reverse causality. In fact, there are strong arguments (i.e., rent sharing) that suggest that changes in performance cause changes in pay. We estimated the models testing lag effects by including a model where the change in pay structures is lagged by one year and a model where the change in performance is lagged by one year. It was found that the model that best fits the data is the concurrent model presented in table 3 . The statistically significant relationships we found were predominantly present in the lagged models. ${ }^{6}$ Data that captures the moment when managers make discrete changes to compensation schemes may be necessary to explore causality more fully. Third, actual compensation is an imperfect proxy for the construct of expected pay. Employees are motivated by the expected relationship between effort and pay, not the actual relationship. A better measure of bonus/base, for example, would be the expected pay from a bonus system, not the actual bonus paid. Fourth, the sample of white-collar employees is certainly not random. We must be careful to not extend these results past the large industrial firms that the sample represents.

Understanding how compensation attributes fit together is an important extension of this research. If, for example, contingent compensation is more effective for motivating top management and efficiency wages are more effective for motivating lower level managers, how will firms match up these systems? In good years, how equitable will top management's large bonuses appear to middle managers? Similarly, how will hiring lower level managers attracted to efficiency wages affect the selection of top managers motivated by contingent compensation?

Additional research that examines the design of compensation plans and also compares the plan design against its selected performance measure is warranted. Although such data are quite difficult and costly to obtain, a clearer understanding of the relationship between intended outcomes of compensation choices and the actual outcomes would be

6. The tournament variable was no longer significant in the lagged performance model at level $=2$ and the pay mix variable was not significant in the lagged pay model in level = 4. All of the other significant relationships remained significant and those that were not significant remained insignificant. 
enlightening. This is particularly pertinent for testing agency models, which generally involve using actual contingent pay as a proxy for expected contingent pay.

Clearly, an important extension of this work would include the addition of other pertinent strategic variables, much like Gomez-Mejia and Balkin (1992) and Gomez-Mejia (1992). Not only would the level of the hierarchy be important to consider, but considering the strategic direction the firm has chosen will also increase the likelihood that the strategic goals will be met.

\section{】 REFERENCES}

AKERLOF, G. and J. YELLEN. 1986. Efficiency Wage Models of the Labor Market. Cambridge: Cambridge University Press.

Allison, P. D. 1990. "Change Scores as Dependent Variables in Regression Analysis." Sociological Methodology 1990. C. C. Clogg, ed. Oxford: Basil Blackwell, 93-114.

BECKER, B. and M. HUSELID. 1992. "The Incentive Effects of Tournament Compensation Systems." Administrative Science Quarterly, Vol. 37, 336350.

Blinder, A. 1990. Paying for Productivity: A Look at the Evidence. Washington, D.C.: Brookings Institution.

Bull, C., A. SCHOTTER and K. Weigelt. 1987. "Tournaments and Piece Rates: An Empirical Study." Journal of Political Economy, Vol. 95, 1-33.

CAmPBell, C. M. 1993. "Do Firms Pay Efficiency Wages? Evidence with Data from Production and Clerical Jobs." Industrial and Labor Relations Review, Vol. 46, 515-530.

CAPPElli, P. and W. F. CaScio. 1991. "Why Some Jobs Command Wage Premium: A Test of Career Tournament and Internal Labor Market Hypotheses." Academy of Management Journal, Vol. 34, 848-868.

CAPPELLI, P. and K. CHAUVIN. 1991a. "An Interplant Test of the Efficiency Wage Hypothesis.” Quarterly Journal of Economics, Vol. 103, 769-787.

CAPPELLI, P. and K. Chauvin. 1991b. "A Test of an Efficiency Wage Model of Grievance Activity." Industrial and Labor Relations Review, Vol. 45, 3-14.

Coughlin, A. and R. Schmidt. 1985. "Executive Compensation, Management Turnover, and Firm Performance: An Empirical Investigation." Journal of Accounting and Economics, Vol. 7, 43-66.

DECKOP, J. R. 1988. "Determinants of Chief Executive Officer Compensation." Industrial and Labor Relations Review, Vol. 41, 215226. 
EDWARDS, J. R. 1994. "Regression Analysis as an Alternative to Difference Scores." Journal of Management, Vol. 20, 683-689.

EHREnBERG, R. G. 1990. "Do Compensation Policies Matter? Ithaca, N.Y.: ILR Press.

EhrenBerG, R. G. and G. T. MiLKOVICH. 1987. "Compensation and Firm Performance." Human Resources and the Performance of the Firm. Morris Kleiner et al., eds. Madison, Wisc.: Industrial Relations Research Association.

EHRENBERG, R. G. and M. L. BognanNo. 1990. "Do Tournaments Have Incentive Effects?" Journal of Political Economy, Vol. 98, 1307-1324.

EISENHARDT, K. 1989. "Agency Theory: An Assessment and Review." Academy of Management Review, Vol. 14, 57-74.

FINKEL, S. E. 1995. Causal Analysis with Panel Data. Thousand Oaks, Calif.: Sage Publications.

GERHART, B. and G. T. MilKOVICH. 1990. "Organizational Differences in Mangerial Compensation and Financial Performance." Academy of Management Journal, Vol. 33, 663-691.

GerharT, B., G. T. MilKOVICH and B. MuRRay. 1992. "Pay, Performance, and Participation." Research Frontiers in Industrial Relations and Human Resources. D. Lewin et al., eds. Madison, Wisc.: Industrial Relations Research Association.

GiBBONS, R., and K. J. MuRPHY. 1990. "Relative Performance Evaluation for Chief Executive Officers." Industrial and Labor Relations Review, Vol. 43, 30-51.

Gomez-MEJIA, L. R. 1992. "Structure and Process of Diversification, Compensation, and Firm Performance." Strategic Management Journal, Vol. 13, 381-397.

GomeZ-MEJIA, L. R. and D. B. BALKIN. 1992. Compensation, Organizational Strategy, and Firm Performance. Cincinnati, Ohio: South-Western.

Groshen, E. L. 1988. "Do Wages Vary Among Employers?" Economic Review, Vol. 24, 19-38.

Groshen, E. L. and A. B. KRUEGer. 1990. "The Structure of Supervision and Pay in Hospitals." Industrial and Labor Relations Review, Vol. 43, 134S-146S.

JENSEN, M. C. and W. H. MECKLING. 1976. "Theory of the Firm: Managerial Behavior, Agency Costs, and Ownership Structure." Journal of Financial Economics, Vol. 3, 305-360.

Jensen, M. C. and K. J. MurPhy. 1990. "Performance Pay and Top Management Incentives." Journal of Political Economy, Vol. 98, 225264.

KERR, J. and R. A. BETTIS. 1987. "Board of Directors, Top Management Compensation, and Shareholder Returns." Academy of Management Journal, Vol. 30, 645-665. 
KERR, J. and L. KREN. 1992. "Effect of Relative Decision Making on Chief Executive Compensation." Academy of Management Journal, Vol. 35, 370-397.

KlEINER, M., R. BlOCK, M. RoOmKIN, and S. W. SAlSBURG. 1987. Human Resources and the Performance of the Firm. Madison, Wisc.: Industrial Relations Research Association.

LAMBERT, R. A., D. F. LARCKER, and K. WeigelT. 1991. "How Sensitive is Executive Compensation to Organizational Size?" Strategic Management Journal, Vol. 12, 395-402.

LAMBERT, R. A., D. F. LARCKER, and K. WEIGELT. 1993. "The Structure of Organizational Incentives." Administrative Science Quarterly, Vol. 38, 438-461.

LAZEAR, E. 1992. "Compensation, Productivity, and the New Economics of Personnel." Research Frontiers in Industrial Relations and Human Resources. D. Lewin et al., eds. Madison, Wisc.: Industrial Relations Research Association.

LEONARD, J. S. 1987. "Carrots and Sticks: Pay Supervision and Turnover." Journal of Labor Economics, Vol. 5, s136-s153.

LEONARD, J. S. 1990. "Wage Structure and Dynamics in the Electronics Industry." Industrial and Labor Relations Review, Vol. 43, 13S-29S.

LEVINE, D. I. 1992. "Can Wage Increases Pay for Themselves? Tests with a Production Function." Economic Journal. Vol. 102, 1102-1115.

LEVINE, D. I. 1993. "What Do Wages Buy?" Administrative Science Quarterly, Vol. 38, 462-483.

LEVINTHAL, D. 1988. "A Survey of Agency Models of Organizations." Journal of Economic Behavior and Organization, Vol. 9, 153-185.

LEWELLEN, W., C. LODERER, K. MARTIN and G. Blum. 1992. "Executive Compensation and the Performance of the Firm." Managerial and Decision Economics, Vol. 13, 65-74.

MURPhY, K. J. 1985. "Corporate Performance and Managerial Remuneration: An Empirical Analysis." Journal of Accounting and Economics, Vol. 7, 11-42.

O'REILly, C. A., B. MAIN and G. F. ChrYSTAL. 1988. "CEO Compensation as Tournament and Social Comparison: A Tale of Two Theories." Administrative Science Quarterly, Vol. 33, 257-274.

Rosen, S. 1986. "Prizes and Incentives in Elimination Tournaments." American Economic Review, Vol. 76, 701-715.

SPITZ, J. 1993. "Workforce Response to an Efficiency Wage." Industrial Relations Research Associations Proceedings, Vol. 45, 142-150.

TISAK, J. and C. S. SMITH. 1994. "Defending and Extending Difference Score Methods." Journal of Management, Vol. 20, 675-682. 
TOSI, H. L. and L. R. GOMEZ-MEJIA. 1989. "The Decoupling of CEO Pay and Performance: An Agency Theory Perspective." Administrative Science Quarterly, Vol. 34, 169-189.

TOSI, H. L. and L. R. GOMEZ-MEJIA. 1994. "Compensation, Monitoring, and Firm Performance." Academy of Management Journal. Vol. 37, 10021016.

Weigelt, K., J. DukERICH and A. SChotTER. 1989. "Reactions to Discrimination in an Incentive Pay Compensation Scheme: A GameTheoretic Approach." Organizational Behavior and Human Decision Processes, Vol. 44, 26-44.

WERnER, S. and H. L. TOSI. 1995. "Other People's Money: The Effects of Ownership on Compensation Strategy and Managerial Pay." Academy of Management Journal, Vol. 38, 1672-1691.

\section{RÉSUMÉ}

La structure de rémunération des cols blancs et les résultats atteints par l'organisation

On ne s'étonne pas de la grande attention que la recherche accorde à la rémunération (voir, par exemple, Kleiner et coll. 1987; Blinder 1990; Ehrenberg 1990) étant donné le temps et l'énergie que les entreprises consacrent à concevoir leur régime de rémunération et l'incidence des salaires sur les coûts d'exploitation. En effet, le rapport entre la rémunération des cadres supérieurs et les résultats atteints par l'entreprise a été minutieusement scruté par les chercheurs (Coughlin et Schmidt 1985; Jensen et Murphy 1990; Kerr et Bettis 1987; Lewellen et coll. 1992; Murphy 1985; Tosi et Gomez-Mejia 1989 et 1994). Dans le même ordre d'idées, les différences de salaire des cols bleus entre les entreprises et les industries ont aussi fréquemment fait l'objet de recherche (Groshen 1988; Leonard 1988). Par contre, relativement peu d'attention a été consacrée à l'étude de la rémunération des cadres intermédiaires (à l'exception de Werner et Tosi (1995) qui se sont penchés sur la rémunération des cadres intermédiaires et la structure du capital social). Dans la présente étude, j'étends donc à ces derniers les thèmes de la recherche déjà effectuée sur la rémunération des cadres supérieurs et des travailleurs de la production, et, plus particulièrement, j'examine comment la structure de leur rémunération est liée aux résultats atteints par l'organisation.

Les principales théories économiques utilisées dans la plupart des études sur la rémunération : théorie de l'intérêt du mandataire, théorie de 
salaires basés sur le rendement, théorie du modèle de compétition, etc., lient le régime de rémunération au rendement de l'entreprise et semblent appliquer plus ou moins également ce principe aux employés de tous les échelons de l'organisation. Cependant, un examen plus attentif laisse voir que certaines théories peuvent être plus pertinentes à certains échelons qu'à d'autres. Les différences dans la manière d'appliquer les postulats aux divers niveaux de la hiérarchie peuvent expliquer les résultats variables constatés dans certains tests empiriques antérieurs portant sur la rémunération et le rendement.

En suivant la théorie de l'intérêt du mandataire, la théorie de salaires basés sur le rendement et la théorie du modèle de compétition, je pose comme principe qu'il y a un rapport indéniable entre les rémunérations supplémentaires (primes liées au rendement financier), les salaires basés sur le rendement (salaires supérieurs à ceux du marché) et les récompenses de promotion (augmentation salariale qui accompagne une promotion) et les résultats financiers de l'entreprise. De plus, je sous-entends que l'incidence des rémunérations supplémentaires sur le rendement est plus grande au niveau supérieur formé des cols blancs qu'au niveau inférieur formé des cols bleus; que l'incidence des salaires basés sur le rendement est plus importante à ce dernier niveau qu'au premier; enfin, que l'incidence des récompenses de promotion est plus grande au niveau supérieur qu'au niveau inférieur.

Je réponds donc affirmativement à la première question posée dans la présente étude, à savoir : est-ce que la relation entre la rémunération et le rendement varie selon le niveau de la hiérarchie? La preuve démontre en effet que le lien entre la rémunération et le rendement n'est pas le même pour les gestionnaires et le personnel de niveau inférieur que pour les gestionnaires de niveau supérieur.

Ce résultat initial est important pour un certain nombre de raisons. Il apparaît d'abord que lier la rémunération des cadres supérieurs au rendement financier de l'entreprise est plutôt un moyen direct de réduire les problèmes de l'organisation, mais il se peut par ailleurs que ce ne soit pas le meilleur moyen de susciter l'effort et l'intérêt des cadres intermédiaires. En réalité, les salaires basés sur le rendement sont plus propices à motiver les cadres intermédiaires. Lorsqu'ils conçoivent les stratégies de rémunération, les gestionnaires doivent donc se demander dans quelle mesure l'incidence potentielle d'un régime de rémunération choisi s'accorde avec l'incidence recherchée.

Les résultats à l'appui des hypothèses de la théorie de l'intérêt du mandataire laissent supposer que cette théorie a valeur de prévision pour les niveaux supérieurs de l'organisation, mais que cette valeur est moin- 
dre pour le niveau inférieur formé des cols blancs. Le manque de lien étroit entre les rémunérations supplémentaires et le rendement de l'entreprise aux niveaux inférieurs peut provenir de problèmes propres à ce niveau. Par exemple, il peut être difficile pour ces employés de percevoir le lien entre des efforts accrus et la hausse de prime.

La théorie de salaires basés sur le rendement est confirmée avec plus de force au niveau inférieur des cols blancs qu'elle ne l'est aux niveaux supérieurs. C'est peut-être dû au fait que les salariés des niveaux supérieurs possèdent des compétences plus particulières que ceux des niveaux inférieurs, et que, par conséquent, on ne peut leur appliquer les comparaisons du marché essentielles à l'utilisation de la théorie de salaires basés sur le rendement. Il se peut également que les travailleurs des échelons inférieurs soient moins motivés par les salaires supplémentaires en raison de problèmes qui leur sont propres. Ces travailleurs pourraient être plus fortement influencés par les salaires basés sur le rendement en raison du lien de récompense ou de punition plus direct établi par ce genre de rémunération. Compte tenu de la décroissance de la sécurité d'emploi parmi les cols blancs, il serait intéressant d'examiner si les salaires basés sur le rendement versés à ces travailleurs suscitent de plus grands efforts.

Les résultats confirment faiblement la théorie du modèle de compétition. La hausse ou la baisse de rendement est fonction de l'importance de la récompense uniquement pour les gestionnaires responsables des superviseurs (niveau 2). Le lien entre le niveau de la hiérarchie et le changement dans le rendement est beaucoup plus fort au niveau 2 qu'aux autres niveaux. Cette constatation accorde un certain appui à la théorie voulant que les incitatifs fondés sur la compétition exercent une plus grande incidence sur les gestionnaires supérieurs que sur les cols blancs.

La confirmation plus ou moins forte de chacun des modèles de rémunération aux différents échelons de l'organisation peut expliquer en partie les résultats variables constatés dans les études antérieures. Par exemple, le manque d'appui à la théorie de salaires basés sur le rendement au niveau des cadres supérieurs ne signifie pas le rejet de cette théorie, mais peut signifier celui de ce modèle pour les catégories d'employés possédant des compétences particulières. De même, la théorie du modèle de compétition peut avoir plus de valeur de prévision pour ces employés qui se voient dépendants du marché du travail interne et de la concurrence en matière de promotion. La recherche à venir pourrait porter sur la compréhension des perceptions des employés relativement aux caractéristiques du régime de rémunération et la façon dont ces perceptions motivent le comportement. 
Les résultats de la présente recherche sont importants pour les gestionnaires de la rémunération. En montrant que les changements apportés au régime de rémunération modifient le rendement de l'entreprise, ils laissent d'abord voir que la conception du régime de rémunération peut avoir des effets considérables sur l'organisation. Ensuite, la confirmation des trois théories économiques sur la rémunération indique que les gestionnaires de la rémunération doivent intégrer diverses caractéristiques à leur régime de rémunération. Enfin, et c'est le plus important, il n'y a pas un régime de rémunération qui conviendrait à toutes les entreprises. Chacune doit concevoir le sien et y intégrer les caractéristiques qui conviennent à chaque catégorie d'employés. Un régime de souscriptions à des actions peut être approprié pour les cadres supérieurs mais sans intérêt pour les gestionnaires de niveau inférieur. Par contre, ces derniers peuvent être très motivés par un régime de rémunération qui prévoit des salaires basés sur le rendement. De bons gestionnaires concevront donc des régimes de rémunération qui présentent les diverses caractéristiques les mieux appropriées à leur main-d'œuvre et aux moyens de l'entreprise.

\section{RESÚMEN}

La estructura de compensación de los empleados de oficina y la organización eficiente

Usando una selección de datos única, analicé la relación entre la compensación patronal y cambios en la eficiencia de la empresa descendiendo en la jerarquía de la organización. Encontré que existen diferencias entre los modelos de compensación por eficiencia, por agencia o por torneo basadas en los diferentes niveles de la organización. Los resultados dan peso a la noción que una variedad de modelos puede ser necesaria para explicar las estrategias de compensación en las organizaciones 